\title{
Robert Duncan Catterall, CBE, FRCP, FRCPE
}

Duncan Catterall died, peacefully at home, on 5 May 1993 after a long illness. He was one the most distinguished post-war British venereologists (genitourinary physician). Unlike most of the others he only entered medicine after the war. He had originally begun to follow his father in the family cotton manufacturing firm and had hoped to become a captain of industry. The Second World War intervened and his experiences during this period caused a change of course and determined the future direction of his life.

Although he hated violence and thought that war was evil, Catterall was not a conscientious objector. However, driving an ambulance to help the wounded appealed to him and he joined a Friends' Field Ambulance and was sent to the Winter War. When the Russians overran the Karelian isthmus the unit retreated to Norway, then being invaded by the Germans, and he escaped to internment in Sweden. Managing his release, he rejoined British forces in Egypt via Russia, Turkey and Palestine but, on being sent to Greece and chosing to stay with British wounded, he was captured and spent the rest of the war as a POW. He escaped subsequently in the Alps, on being transferred to Germany, but was recaptured on the Swiss border. Working as a medical orderly in the camps persuaded him to take up medicine when the war was over. Additionally, from a fellow French POW he learnt to speak French fluently.

After graduating from the London Hospital Medical College he commenced training in venereology under the auspices of $\mathrm{Mr}$ Ambrose King, at the Whitechapel Clinic. He spent a year at the famous syphilology clinic at the Johns Hopkins Hospital in Baltimore with Professor Paul Turner, a great Anglophile. The incidence of syphilis and gonorrhoea were in rapid decline at that time and he disagreed with those who tried to dissuade him from continuing in the specialty on the grounds that one of the few constant things in life is human nature. He was proved correct when the incidence of the sexually transmitted diseases began to rise again at the end of the 1950s.

Upon return to the United Kingdom he found a paucity of available consultant posts and for a while was an SHMO at St Thomas' Hospital, London. In 1959 he was appointed to the General Infirmary at Leeds as consultant venereologist and rapidly turned around a run-down department. In 1964 he returned to London upon appointment to The Middlesex Hospital which, at that time, was the only teaching hospital in the United Kingdom without a department of venereology. The hospital had long resisted such an appointment but, despite a few prickly colleagues, he established James Pringle House, the first modern clinic in the capital. He was determined to make it different and arranged for it to be well-appointed and welcoming. Patients were referred to by name and were offered appointments, a new departure at that time. Catterall travelled widely and many of the doctors he met overseas visited him, lending an international flavour to the department.

Although of formal dress and appearance, he fitted in well with the ambience of central London in the 1960s and '70s. Patients from the worlds of the Arts and the media and from the commercial world used the clinic and he soon built up a large homosexual male clientele because of the sympathetic way in which patients were handled. Catterall was urbane, civilised and a bon viveur, as well as a connoisseur of fine wines and he enjoyed the proximity of his department to good restaurants. He was an inspired and popular teacher and he soon became involved, in its early days, with the London Medical Group subsequently becoming Chairman of its Consultative Council and through that became a founder member of the editorial board of the Journal of Medical Ethics.

$\mathrm{He}$ was also a man of foresight and realised, along with Doctors Claude Nicol and Jimmy Fluker, that Genitourinary Medicine, as a name, better described the activities of the field. Together they lobbied successfully for the change. He recognised the need to create an academic base with his specialty and was wholly responsible for the establishment, and endowment, of the first Chair of Genitourinary Medicine at The Middlesex Hospital Medical School, in 1979. $\mathrm{He}$ also recognised the need to set standards in his field and established, at the Society of Apothecaries of London, a Diploma in Venereology (now Genitourinary Medicine) in 1973.

$\mathrm{He}$ was an effective committee man and was, at various times, President of the Medical Society for the Study of Venereal Diseases and the International Union Against the Venereal Diseases and Treponematoses, within which he established a new African branch. He served on the Union of European Monospecialty Committees where his linguistic abilities were most helpful and he sat on a 
number of the World Health Organisation's expert advisory committees. He was also Adviser to the Department of Health for England and Wales and to the British Army.

Duncan Catterall was a generalist within his discipline, but he was one of the last British physicians with extensive experience of the later forms of syphilis. He was a meticulous physician and demanded the highest standards from his staff. He was above fashion and his sartorial elegance in his department and on the wards in his well-tailored suits, always with turn-ups when they were not necessarily de rigeur, detached collars and gleaming shoes was greatly admired by his patients, as much as by his staff. The sensitive and polished way in which he dealt with anxious patients was therapeutic in itself. It was much appreciated by them and gave his staff something to emulate. His opinion was widely sought by physicians, surgeons and gynaecologists throughout his hospital His presence semed to prompt colleagues to include genitourinary disorders in their differential diagnoses. He was prepared to manage a whole range of medical problems when they occurred in his patients; indeed, he looked after the first AIDS patients at The Middlesex Hospital, just before he retired in 1983.

The Medical Society for the Study of Venereal Diseases honoured him with the Harrison Lecture after he retired and he had previously been awarded the Thomas Parran Award by the American Venereal Diseases Association. The Government of Finland honoured him for his part in the Winter War, at the end of hostilities, and he was appointed $\mathrm{CBE}$ in 1983, just before he retired. $\mathrm{He}$ thought that this was an unbelievable honour for doing a job that he loved.

Duncan Catterall considered it a privilege to treat patients and disapproved of the decision to pay doctors in training overtime. $\mathrm{He}$ was wise, kind and good, and an optimist and those of us who had the opportunity to work with him were most fortunate.

JS BINGHAM 